\title{
Hvad lærer de studerende, at de skal lære? En un- dersøgelse af kandidatstuderendes opfattelse og brug af læringsmål
}

Thomas Clausen, adjunkt, ph.d., Danmark Institut for Pædagogik og Uddannelse, Aarhus Universitet

Helle Hvass, konsulent, Center for Undervisningsudvikling og Digitale Medier, Aarhus Universitet

\section{Videnskabelige artikel, fagfællebedømt}

Tydelige og præcist formulerede læringsmål er et afgørende grundlag for den studerendes eksamenspræstation. Derfor er det vigtigt, at de studerende kender til læringsmålene for de fag, de følger, og forstår dem. Alligevel synes der at herske forskellige opfattelser blandt studerende og undervisere af, hvor centralt beskæftigelsen med læringsmål står i undervisning og forelæsninger. Denne artikel fokuserer på de studerendes tilgang til læringsmål. Vi baserer undersøgelsen på kvalitativ og kvantitativ empiri og udleder tre analysespor, som vi forfølger: de studerendes forståelse af læringsmål, de studerendes brug af læringsmål og de studerendes kritiske stillingtagen til læringsmål. Resultaterne af undersøgelsen peger bl.a. på, at studerende efterspørger en nærmere forbindelse mellem undervisning og læringsmål. Artiklen argumenterer i forlængelse heraffor, at et udvidet fokus på de såkaldte "tærskelbegreber" kan bidrage til at højne opmærksomheden på læringsmål i undervisningen og hjælpe med at koble undervisningens indhold til kvalifikationsbeskrivelsen.

\section{Indledning}

Formulering af og udprøvning efter modulspecifikke kvalifikationsbeskrivelser opdelt i videns-, færdigheds- og kompetencemål er centrale elementer i de danske universiteters undervisningsforpligtelse. Det følger af de seneste årtiers internationale udvikling på uddannelsesområdet, som har medført en gradvis og glidende bevægelse fra opmærksomhed på undervisningsmidler og vidensoverførsel (input) til refleksioner over, hvordan de studerende rent faktisk sættes i stand til at anvende det lærte (output) (Altbach, Reisberg og Rumbley 2009: 111f; CEDEFOP 2009). Et aktuelt og overordnet indsatsområde for uddannelsesinstitutionerne er derfor at få de studerende til at tænke mere i læringsmål og mindre i pensum (Danmarks Evalueringsinstitut 2013: 7). Men hvad ved vi egentlig om de studerendes tilgang til og brug af læringsmål? Og hvordan opfatter de studerende sammenhængen mellem de opstillede læringsmål og indholdet af den undervisning, de følger? Den universitetspædagogiske forskning, som er publiceret i Dansk Pædagogisk Tidsskrift, har generelt ikke set nærmere på de mål, som er opstillet for undervisningen på de danske universiteters forskellige uddannelser (Keiding og Qvortrup 2015: 16). Ligeledes synes der i den internationale forskningslitteratur ikke at findes nogen klare og gennemgående svar på, hvordan studerende og undervisere forholder sig til den læringsmålsbaserede undervisning i praksis (Sin 2013; Dobbins et al. 2016).

I denne artikel undersøger vi på et empirisk grundlag, hvordan en årgang af studerende på kandidatuddannelsen i uddannelsesvidenskab, Aarhus Universitet (AU), forholder sig til og anvender 
læringsmål. I forlængelse heraf giver vi et teoretisk baseret bud på, hvordan forbindelsen mellem læringsmål og undervisning i praksis kan styrkes. Vi opstiller i vores undersøgelsesdesign en analysemæssig parallelitet til kvalifikationsrammens begrebssæt i tilknytning til læringsudbyttet ved at fokusere på de studerendes forståelse af læringsmål (viden), brug af læringsmål (færdigheder) og kritiske stillingtagen til læringsmål (kompetence). Det gør vi for at få belyst de studerendes tilgang til læringsmål fra forskellige vinkler og på flere niveauer. Samtidig illustrerer spørgsmålsstrukturen den underliggende pointe, at forståelse, brug og stillingstagen har tendens til at være sammenflydende, på samme måde som grænserne mellem taksonomien af viden, færdigheder og kompetencer ikke altid forekommer at være fuldt optrukne. Erkendelsesmæssigt er vores interesse således at komme bag om den umiddelbart observérbare inddragelse af læringsmål $\mathrm{i}$ undervisningssammenhæng for i stedet at fokusere på, hvordan de studerende forholder sig til kvalifikationsbeskrivelserne og tager dem i anvendelse.

Med "forståelse" henviser vi til to forhold: dels de studerendes generelle bevidsthed om læringsmålenes ophav - hvorfor har vi dem? Hvor kommer de fra? - dels den oplevede tydelighed af læringsmålene: Er det ud fra formuleringerne som hovedregel klart, hvad der skal læres, og hvad de studerende i sidste ende bliver bedømt på til eksamen? Med "brug" sigter vi til, hvordan de studerende konkret anvender læringsmålene: På hvilke tidspunkter $i$ et undervisningsforløb læser de studerende læringsmålene? Spiller læringsmålene nogen rolle i det kollektive forberedelsesarbejde blandt de studerende, eksempelvis i studiegrupper? Endelig ønsker vi at unders $\varnothing$ ge de studerendes holdning eller "kritiske stillingtagen" til læringsmål som fænomen: Finder de studerende selv, at tilstedeværelsen af læringsmål understøtter deres læring? Oplever de konsistens i den måde, læringsmålene inddrages i undervisningen på fra underviser til underviser? Disse spørgsmål vil alle blive givet opmærksomhed i artiklens analyseafsnit. Samlet set, og med udgangspunkt i ovenstående operationalisering, ønsker vi at besvare følgende forskningsspørgsmål:

\section{Hvad kendetegner de studerendes tilgang til læringsmål?}

Artiklen er inddelt i fem hovedafsnit. Indledningsvis gør vi rede for de funktioner, læringsmål har i de danske universitetsuddannelser, og tegner problemfeltet op. I andet afsnit beskriver vi konteksten for vores studie: modulet "Forvaltning - i et uddannelsesvidenskabeligt perspektiv" på kandidatuddannelsen i uddannelsesvidenskab ved Danmarks Institut for Pædagogik og Uddannelse (DPU), AU, samt redeg $\varnothing r$ for artiklens teoretiske grundlag. Herefter følger i et tredje afsnit en nærmere behandling af vores metode, analysestrategi og undersøgelsesdesign. I det fjerde afsnit analyserer og diskuterer vi vores empiri ud fra det opstillede forskningsspørgsmål. Endelig samler vi i det sidste afsnit op i en konklusion.

\section{Læringsmål i de danske universitetsuddannelser}

De danske universiteter er lovmæssigt forpligtede til at yde forskningsbaseret uddannelse indtil højeste internationale niveau (Uddannelses- og Forskningsministeriet 2015). De udbudte uddannelsesforløb er i hovedreglen struktureret som 3-årige bachelor- og 2-årige kandidatforløb tilrettelagt som heltidsuddannelser med udgangspunkt i den danske kvalifikationsramme for livslang læring efter Bolognaprocessens mønster (Brøgger og Clausen 2017; Andersen og Jacobsen 2012). Den enkelte uddannelse er konstitueret af et antal afgrænsede moduler, der som hovedregel afsluttes med én eller anden form for eksamenshandling (Uddannelses- og Forskningsministeriet 2016a). Gennem de senere år er tilgangen af studerende på de videregående uddannelser steget 
markant (Uddannelses- og Forskningsministeriet 2017). Udprøvning af studerende er derfor et voksende, og ofte ressourcekrævende, arbejdsområde for det videnskabelige personale på de videregående uddannelsesinstitutioner.

Formålet med eksamen på universiteterne er, ifølge gældende eksamensbekendtgørelse, "at bedømme, i hvilken grad de studerende opfylder de faglige mål", der er fastsat for det enkelte modul (Uddannelses- og Forskningsministeriet 2016b). Disse faglige mål er almindeligvis udmøntet $\mathrm{i}$ en kvalifikationsbeskrivelse, altså nogle udspecificerede læringsmål, der - sammen med studieordningens overordnede vurderingskriterier - ligger til grund for eksamensbed ømmelse af den studerende. Det enkelte moduls kvalifikationsbeskrivelse er ideelt set en mere detaljeret afspejling af den overordnede kompetenceprofil for den pågældende uddannelse, som igen er formuleret med udgangspunkt i værdier og målsætninger på institut-, fakultets- og institutionsniveau (Biggs og Tang 2011: 114f; Keiding 2016). Det er i den sammenhæng vigtigt at understrege, at læringsmålene udtrykker det forudbestemte og intenderede udkomme af et undervisningsforløb (hvad den studerende "skal kunne") og således ikke udelukker, at der samtidig finder andre, positive læringsudbytter sted. Denne iagttagelse har fået nogle forskere til at tale om "fremkommende læringsmål" (emergent learning outcomes) som en mere uformel, fleksibel og løbende målkategori (Hussey og Smith 2003). Skønt vi anerkender den analysemæssige værdi af denne tilgang til læringsmål, vil vi i denne artikel alene se på de formelle, studieordningsbaserede læringsmål. Dog inddrages de som oftest ikke-formaliserede "tærskelbegreber" i analysen, jf. nedenfor. Vi afgrænser os desuden fra den pædagogiske forskningsdiskussion om konsekvenserne af målstyret undervisning. Læringsmål er en del af de studerendes virkelighed, lige meget om man som underviser og forsker er for eller imod dem.

Kompetenceprofil og kvalifikationsbeskrivelser tjener tilsammen flere formål. For det første fungerer især kvalifikationsbeskrivelsen, som nævnt, som et formelt bedømmelsesgrundlag for en eksamenspræstation i forbindelse med eksaminators og censors votering. Den studerendes opfyldelse af læringsmålene er derfor tæt koblet til karakterudmålingen (Caspersen, Smeby og Aamodt 2017: 4f). Fra den studerendes perspektiv kan læringsmålene desuden anskues som en form for retssikkerhed mod vilkårlighed i karakterfastsættelsen. Læringsmålene udgør således på flere måder en vigtig del af det eksamensretlige grundlag og kan som sådan i yderste konsekvens fungere som udgangspunkt for en eksamensklage, hvor den studerende mener at have opfyldt fagets mål i højere grad, end den udmålte karakter indikerer (Schmidt 2006: 9). Det er derfor vigtigt, at de studerende kender til læringsmålene for de fag, de følger, og forstår indholdet af dem.

For det andet opfylder de formulerede læringsmål et informationsbehov hos allerede indskrevne eller kommende studerende samt andre interessenter (Referencegruppen 2007; Reinecker et al. 2013). Denne signalgivning er så meget desto vigtigere på Arts (AU), hvor studieordningernes supplerende indholdsbeskrivelser ofte er forholdsvis sparsomme (Keiding 2016: 10). Ved at konsultere kvalifikationsbeskrivelsen bør den udenforstående altså, i princippet, kunne danne sig et indledende overblik over det fagspecifikke indhold $i$ et modul.

Endelig for det tredje kan læringsmålene fungere som et strukturerende, didaktisk arbejdsredskab for studerende gennem et undervisningsforløb. I denne optik udg ør læringsmålene en form for "manual" eller tjekliste, som den studerende kan konsultere og vende tilbage til, efterhånden som undervisningsforløbet skrider frem, med henblik på at understøtte og optimere sin læring. 
Denne anvendelse af læringsmål har været overset i tidligere studier, men falder inden for denne artikels undersøgelsesområde.

Læringsmål på universiteterne er altså vigtige størrelser. Derfor er det essentielt, at de studerende får oparbejdet et dækkende kendskab til kompetenceprofil og kvalifikationsbeskrivelser for den uddannelse, de har valgt. Det er en opgave, som vedrører både institutionsledelsen, underviserne og de studerende selv. Da læringsmålene beskriver, hvilke(n) viden, færdigheder og kompetencer, de studerende forventes at have tilegnet sig ved modulets afslutning, er det desuden efterstræbelsesværdigt, at kvalifikationsbeskrivelse, undervisningsindhold og eksamensform er afstemt i rimelig grad (alignment). AU har da også som mål for sin officielle kvalitetspolitik at sikre denne sammenhæng, herunder at læringsmål formuleres og kommunikeres klart til de studerende (Danmarks Akkrediteringsinstitution 2017: 55).

Resultaterne af nyere danske studier antyder, at forbindelsen mellem undervisningens indhold og de opstillede læringsmål kunne være mere solid. I en større, tværfakultær undersøgelse af studerendes og underviseres perspektiver på undervisningen på AU gennemført i 2016 svarede $89 \%$ af de adspurgte undervisere, at de tydeligt definerer læringsmålene i deres undervisning, mens blot $59 \%$ af de studerende fandt, at det var tilfældet (Thingholm et al. 2016: 24). Et andet studie, baseret på opgavebesvarelser fra 116 deltagere i tre forskellige adjunktkursusforløb ved AU i perioden 2011-2012, har vist, at studieordningen, og dermed modulernes kvalifikationsbeskrivelser, typisk er et underordnet kriterie, når undervisere vælger indhold på de enkelte fag ved Arts, mens til gengæld hævdvundne og/eller fagspecifikke modeller, teorier og problemstillinger er mere afgørende parametre (Keiding og Hansen 2012). Disse resultater gør det relevant at spørge, hvordan den læringsmålsorienterede undervisning ser ud fra et studenterperspektiv, samt hvordan læringsmål og undervisning i højere grad kan sammentænkes.

\section{Kontekst og teori}

Modulet "Forvaltning - i et uddannelsesvidenskabeligt perspektiv" er placeret på 2. semester af kandidatuddannelsen i uddannelsesvidenskab, som er en samfundsvidenskabelig uddannelse på DPU. Faget er en obligatorisk del af uddannelsen (ikke et valgmodul) og har et studiemæssigt omfang af 10 ECTS-point. Der var i forårssemesteret 2017, da undersøgelsen fandt sted, 115 indskrevne studerende på modulet fordelt, om end ikke helt ligeligt, på instituttets to uddannelsessteder, Campus Aarhus og Campus Emdrup. Omtrent halvdelen af de studerende havde professionsbachelorbaggrund, fortrinsvis skolelærere, mens den anden halvdel med et groft skøn fordelte sig nogenlunde ligeligt mellem bachelorer i uddannelsesvidenskab og andre universitetsbachelorer fra især humanistiske studieretninger.

Modulets kvalifikationsbeskrivelse ${ }^{1}$ (figur 1) er bygget op om en taksonomi af læringsmål fordelt på viden, færdigheder og kompetencer, jf. den nationale kvalifikationsramme for livslang læring (Uddannelses- og Forskningsministeriet 2008).

${ }^{1}$ Læringsmålene undergår aktuelt en revision som følge af udarbejdelsen af en ny studieordning for kandidatuddannelsen i uddannelsesvidenskab. Den gældende studieordning er fra 2013. 
Viden

- om offentlig forvaltning og forvaltningens opbygning, nyere historie og funktionsmåde samt modulets grundlæggende teorier, metoder og sagsforhold.

- om forholdet mellem embedsmænd og det politiske system på de forskellige områder nationalt og internationalt, herunder forskellige forvaltningslogikker og -funktioner, med særlig vægt på uddannelsesområdet.

\section{Færdigheder}

- $i$ at identificere, beskrive og analysere teoretiske og praktiske implikationer af forskellige forvaltningsproblemstillinger, herunder at sammenligne og identificere forskelle og ligheder, styrker og svagheder.

- $i$ at anvende teorier og metoder på en given problemstilling eller et givent sagsforhold.

\section{Kompetencer}

- til at dokumentere og selvstændigt vurdere juridiske og andre forvaltningsmæssige omstændigheder og implikationer.

- til at formidle og selvstændigt vurdere modulets teorier og metoder og deres anvendelsesområder $i$ et komparativt perspektiv.

Figur 1: Kvalifikationsbeskrivelse (læringsmål). Forvaltning - i et uddannelsesvidenskabeligt perspektiv

Indlejret i de i alt seks læringsmål kan siges at ligge nogle kerne- og tærskelbegreber (Davies og Mangan 2007). Kernebegreber er fagspecifikke nøgleord, hvoraf nogle typisk vil optræde eksplicit i et moduls kvalifikationsbeskrivelse. I det konkrete tilfælde ville det f.eks. være begreberne "den offentlige forvaltning", "det politiske system" og "embedsmænd", som hver især knytter an til et sæt af bestemte forskningsperspektiver, teorier og fagmæssige anskuelser. Kernebegreberne er centrale begrebsst $\varnothing$ rrelser, som den studerende almindeligvis forventes at blive gjort fortrolig med undervejs i semesteret og typisk skal demonstrere tilstrækkelig indsigt i ved eksamen. Tærskelbegreber indgår derimod sjældent direkte i et moduls kvalifikationsbeskrivelse. De er særlige begreber, som på sæt og vis er overordnet kernebegreberne, og som potentielt kan have transformative læringseffekter ved at åbne op for ny og dyberegående erkendelse af fagfeltet gennem en mere substantiel forståelse af de enkelte kernebegrebers nærmere betydningsindhold (figur 2) (Land et al. 2005: 59-60). Davies og Mangan nævner som eksempel på et tærskelbegreb fra den økonomiske videnskab ordet "offeromkostninger", der kan defineres som tabet af værdi ved valget af det næstbedste alternativ. Begrebet "offeromkostning" befinder sig i kernen af et større fagøkonomisk begrebsnetværk, hvortil f.eks. kernebegreberne elasticitet, komparative fordele og den marginalistiske forståelse knytter sig (Davies og Mangan 2007: 722). I nærværende sammenhæng kan man tilsvarende pege på begrebet "delegation" (se f.eks. Christensen, Christiansen og Ibsen 2017), som er nødvendigt at kende til for at kunne arbejde meningsfuldt med de ovenfor nævnte kernebegreber fra modulets læringsmål, men som ikke indgår direkte i disse. En aktiv inddragelse og eksplicitering af tærskelbegreber i undervisningen, f.eks. i form af casebaserede $\varnothing$ velser, kan ifølge Davies og Mangan være med til at forklare og indholdsbestemme læringsmålenes kernebegreber (Davies og Mangan 2007: 711). I artiklen argumenterer vi for, 
at tærskelbegreber med fordel kan flyttes tydeligere ind $\mathrm{i}$ undervisningen som en måde at højne de studerendes fortrolighed med og interesse for læringsmålene på.

\section{Metode, analysestrategi og undersøgelsesdesign}

For at besvare vores forskningsspørgsmål inddrager vi forskellige typer af data. Den indsamlede empiri til undersøgelsen består således af både kvalitativt og kvantitativt materiale. En sådan kombineret forskningsstrategi muligg $\varnothing$ r, at vi kan udfinde generelle mønstre i vores population, samtidig med at vi frembringer en dybere og mere helhedsorienteret forståelse af vores genstandsfelt (Jensen og Kvist 2016).

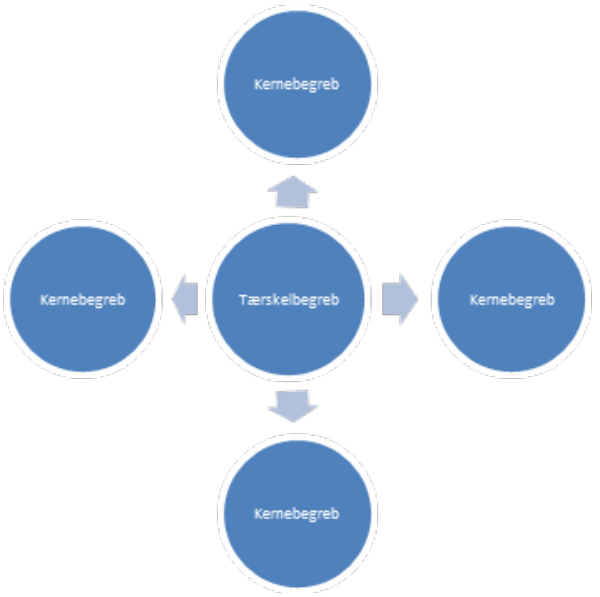

Figur 2: Kerne- og tærskelbegreber

Den kvantitative del af empirien udgøres af et survey i form af en internetbaseret spørgeskemaunders $\varnothing$ gelse udarbejdet ved brug af softwareprogrammet SurveyXact. Spørgeskemaet var konstrueret som et spørgsmålsbatteri baseret på forskellige udsagn om læringsmål, som de studerende skulle forholde sig til på en Likertskala med fem trin samt en "ved ikke"-kategori. Udsagnene omhandlede både læringsmål i almindelighed og modulets læringsmål specifikt. Tilgangen er til dels inspireret af Biggs og Tang, som i deres bredt anvendte lærebog om universitetsundervisning, Teaching for Quality Learning at University (2011), foreslår, at man inddrager de studerende i udlægningen af læringsmål gennem f.eks. brug af spørgeskemaundersøgelser (Biggs og Tang 2011: 284f).

Spørgeskemaet blev udsendt til de studerende umiddelbart ved semesterstart og distribueret via et link i modulets kursusrum på Blackboard ${ }^{2}$ sammen med en kort følgeskrivelse. Populationen for spørgeskemaet var hele årgangen af kandidatstuderende på modulet. Udvalgsrammen var $\mathrm{i}$ begge tilfælde studerende med adgang til Blackboard. De studerende blev introduceret til og adviseret om spørgeskemaerne mundtligt i undervisningen, ligesom der blev lagt en påmindelse om at besvare spørgeskemaerne ud på Blackboard ca. en uge efter offentliggørelsen.

Antallet af fuldt gennemførte besvarelser var 40, mens 2 respondenter blev frasorteret, idet de ikke havde besvaret hele spørgeskemaet. Den nøjagtige svarprocent lader sig af forskellige årsager vanskeligt udregne. Dels er der sjældent fuldkommen overensstemmelse mellem excelarke-

\footnotetext{
${ }^{2}$ Blackboard er den online studieplatform, som AU benytter til kursushåndtering og e-læring.
} 
ne over eksamenstilmeldte og brugerlisterne på Blackboard, hvorfor det ikke kan udelukkes, at enkelte studieaktive studerende ikke har haft adgang til Blackboard. Dels vil der næsten altid figurere såkaldt "spøgelsesstuderende" på samme brugerlister, som egentlig ikke er studieaktive og derfor falder uden for målgruppen. Lægger vi til grund, at alle brugere med status af studerende i det pågældende kursusrum ${ }^{3}$ (115 studerende) har haft mulighed for at besvare spørgeskemaet, ender vi med en svarprocent på $35 \%$. Denne andel, som formentlig overvurderer st $\varnothing$ relsen af den faktiske population en anelse, er relativt beskeden og tillader ikke at foretage vidtgående generaliseringer på baggrund af de foreliggende data. På den anden side er en svarprocent på 35 ikke uden sammenligning med, hvad man finder $\mathrm{i}$ andre forskningsbaserede surveys (Rathlev, Hermansen og Bay 2017: 79f; Bundsgaard og Puck 2016: 10f). Som følge af den relativt lave svarprocent er der ikke foretaget statistisk behandling af datamaterialet, og i det følgende holder vi os alene til frekvensvisninger af udvalgte resultater.

Som opfølgning på spørgeskemaet gennemførte vi syv semistrukturerede forskningsinterviews med studerende fra modulet med udgangspunkt i en interviewguide (Kvale og Brinkmann 2015). Disse interviews blev forestået af den af artiklens forfattere, som ikke har indgået på modulet som underviser, for at fors $\varnothing$ ge at skabe det friest mulige samtalerum for de interviewede. Interviewguiden var udarbejdet med henblik på at belyse vores tre overordnede analysespor. I samtalerne med de studerende spurgte vi således både ind til deres viden om, brug af og holdning til læringsmål generelt og for forvaltningsmodulet specifikt. Desuden forelagde vi dem den tidligere nævnte undervisningsunders $\varnothing$ gelse for at unders $\varnothing g e$, om de kunne genkende dette overordnede billede fra egen undervisningsdeltagelse (Thingholm et al. 2016). Endelig inddrog vi spørgeskemabesvarelserne for at få uddybet relevante punkter mundtligt. F.eks. var vi interesserede i at få belyst, hvorfor et stort mindretal tilsyneladende oplever, at læringsmål generelt giver et mindre tydeligt indtryk af, hvad der skal læres (figur 3).
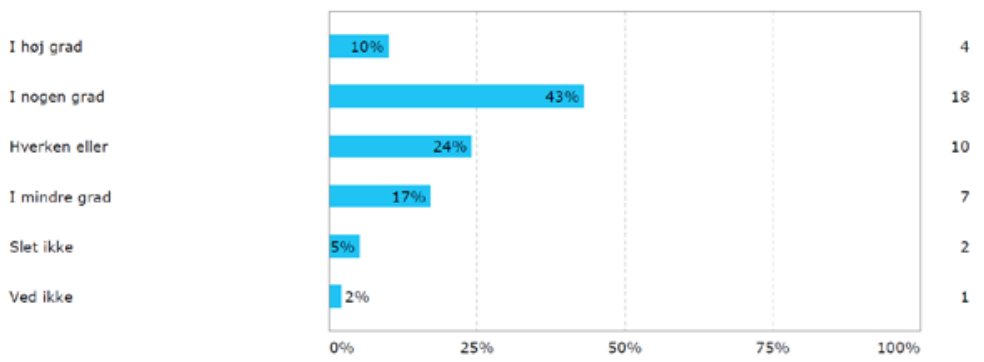

Figur 3. I hvor høj grad passer følgende udsagn på dig? - Jeg synes, at læringsmålene gør det klart for mig, hvad jeg skal lære

De syv studerende meldte sig selv til interviewene og udgjorde ikke et metodisk set repræsentativt udsnit af populationen. Vi interviewede én mand og seks kvinder. Fem havde en bachelorbaggrund fra uddannelsesvidenskab, én var universitetsbachelor fra et humanistisk fag, og én kom med en baggrund som professionsbachelor. Der var afsat en halv time til hvert interview, som blev optaget og efterfølgende transskriberet. ${ }^{4}$

${ }^{3}$ Der er rettelig tale om to kursusrum: ét for Aarhus og ét for Emdrup. For overskuelighedens skyld er disse her analytisk slået sammen til ét rum.

${ }^{4}$ Transskriberingen af vores interviews blev forestået af daværende studentermedhjælper ved 


\section{Analyse og diskussion}

Ud fra vores indsamlede empiri udleder vi tre analysespor, som tilsammen besvarer det forskningsspørgsmål, vi opstillede i indledningen. Vi gennemgår i det følgende de tre analysespor ét for ét med udgangspunkt i data fra spørgeskemaet og de kvalitative interviews. Vi forholder os hovedsagelig deskriptivt og fortolkende til vores empiri, men inddrager undervejs teorien om kerne- og tærskelbegreber. Hvor andet ikke er nævnt, vedrører de fremhævede spørgsmål fra surveyet læringsmål generelt og ikke læringsmålene for modulet om forvaltning specifikt.

\section{Analysespor 1: De studerendes forståelse af læringsmål}

I det første analysespor har vi ønsket at belyse to aspekter ved de studerendes forståelse af læringsmål. For det første har vi været interesseret i at undersøge de studerendes viden om konteksten for overgangen til det mål- og kompetenceorienterede uddannelsesregime, jf. artiklens indledning. Baggrunden for denne interesse er en forventning om, at den viden, de studerende har om læringsmål, generelt har betydning for, hvordan de opfatter og anvender dem (Clement 2017). Konkret spurgte vi ind til vores interviewpersoners bevidsthed om, hvor læringsmål kommer fra, og hvad formålet med læringsmål er inden for videregående uddannelse. Givet at den studiemæssige kontekst er kandidatuddannelsen i uddannelsesvidenskab, var vores antagelse, at vidensniveauet her ville være relativt højt. Det viste sig dog under interviewseancerne, at de studerende havde varierende bud på læringsmålenes ophav. Mens tre af vores interviewpersoner demonstrerede betydelig indsigt i konteksten for opkomsten af læringsmål, udtrykte de sidste fire sig mere undvigende eller upræcist om fænomenet. Et par citater fra vores datamateriale illustrerer de to positioner:

"Det kommer jo fra Bolognaprocessen og er sådan en standardisering af noget, vi i Europa arbejder med: viden, færdigheder og kompetencer. Det er en måde at standardisere, så vi nemmere kan sammenligne. En sammenligningsteknologi." [Interview A]

"Ikke dybere historisk [bevidsthed]. Jeg tænker, at når man tager en uddannelse, så skal man kunne noget bestemt inden for et fagfelt. Jeg tænker, at det er der, det [læringsmålene] kommer fra. Så vi kan afgrænse uddannelser, og så vi ikke allesammen bliver det samme." [Interview D]

En mulig forklaring på variansen i de studerendes udsagn kan være, at forskningslitteraturen om international uddannelsespolitik typisk knytter sig mere til nogle uddannelsesniveauer (videregående uddannelse) end andre. Alt afhængig af de studerendes faglige interesseområder vil de således i større eller mindre grad være stødt på emnet. En anden mulig årsag kan være de studerendes uddannelsesbaggrund (universitets- eller professionsbachelor), som vi desværre ikke har kunnet kontrollere tilstrækkeligt for grundet den manglende repræsentativitet i datamaterialet. Under alle omstændigheder kan vi ikke afgøre ud fra vores empiri, om populationen besidder en forholdsmæssigt stor viden om læringsmål som institution eller ej.

Det andet aspekt, vi har unders $\varnothing$ gt i analysespor 1, er, hvor godt de studerende forstår kvalifikationsbeskrivelsernes ordlyd og begrebsmæssige indhold. Godt halvdelen (53\%) af respondenterne i vores survey svarer, at kvalifikationsbeskrivelserne på denne eller tidligere uddannelser, de

CUDiM, Timian Emilie Thjellesen Valmin, som vi her takker for et godt stykke arbejde. 
har været indskrevet på, enten i høj eller i nogen grad har været forståelige og retningsgivende. 24 \% svarer hverken/eller, mens 17 \% finder, at det kun i mindre grad er tilfældet (figur 3 ). Læringsmålene på forvaltningsmodulet blev tilsyneladende, i hvert fald på tidspunktet for besvarelsen af spørgeskemaet, vurderet til at være mere klart formuleret end den gennemsnittelige kvalifikationsbeskrivelse, idet 88 \% fandt, at læringsmålene i høj grad/nogen grad var forståelige. Vi har under interviewene ikke spurgt direkte ind til, hvad der betingede denne forskel. En nærliggende antagelse er dog, at den pågældende kvalifikationsbeskrivelse rummer flere begreber, som de studerende kender fra tidligere undervisningssammenhænge eller, om ikke andet, den daglige nyhedsstrøm. Til gengæld er den enkelte studerendes subjektive opfattelse af kernebegreberne forbundet med stor usikkerhed. En studerende pegede under interviewet på, at begreberne fra læringsmålene havde tendens til at skifte betydning alt afhængig af den faglige kontekst:

"(...) de begreber, der bliver anvendt, de kan nogle gange - fx i forvaltning - (...) blive brugt igen og igen, men i forskellige sammenhænge, så det faktisk bliver utydeligt, hvad meningen af (sic) det enkelte begreb er. Fx "politisk styring". Det kunne betyde forskellige ting afhængigt af, hvilken kontekst det indgik i." [Interview E]

At begreberne er kontekstafhængige, er en logisk følge af forskningsbaseret uddannelse kendetegnet ved argumentation og faglig dialog. Meyer og Land (2003) argumenterer i den forbindelse for, at inddragelsen af tærskelbegreber kan hjælpe den studerende til at bygge bro mellem ellers umiddelbart modsatrettede begrebsanskuelser. I tilfældet "politisk styring" har modulets undervisere f.eks. alle relateret deres respektive forståelser heraf til tærskelbegrebet "delegation" illustreret gennem modellen over den "parlamentariske styrings- og delegationskæde" (Olsen 1978) for på den måde at skabe et fælles referencepunkt for læringen.

Sammenfattende for analysespor 1 kan vi sige, at de studerendes viden om den uddannelsespolitiske kontekst for læringsmål umiddelbart er mere spredt, end vi forventede. Også når det gælder, hvor klart og tydeligt læringsmål generelt er formuleret på de videregående uddannelser, deler de studerende sig groft sagt i to grupper. Læringsmålenes kernebegreber er kontekstafhængige og opfattes subjektivt af de enkelte studerende.

\section{Analysespor 2: De studerendes brug af læringsmål}

Det andet analysespor handler om, hvornår og i hvilke sammenhænge de studerende bruger læringsmålene. Langt de fleste studerende i vores spørgeskemaunders $\varnothing$ gelse angiver, at de enten i høj grad (43 \%) eller i nogen grad (45 \%) læser læringsmålene inden semesterstart som forberedelse til et undervisningsforløb. Her bliver kvalifikationsbeskrivelsen altså taget i anvendelse som et informationsværktøj. Over halvdelen (knap $60 \%$ ) anvender endvidere modulernes kvalifikationsbeskrivelser som et løbende arbejdsredskab undervejs i semesteret til at vurdere, om de lærer det, de skal lære.

Grundlæggende forholder de studerende i vores interviewmateriale sig relativt pragmatisk til fagenes læringsmål: De konstaterer, at de er der, og forsøger at få det bedste ud af dem. To studerende udtaler f.eks.:

"I udgangspunktet gør jeg ikke [interesserer sig for fagets læringsmål]. (...). Men man kan jo ikke undgå det. Man bliver påduttet det, at skulle gå i de der læringsmål fra dag ét af. Det er måske sådan en tvungen interesse. Jeg interesserer mig ikke for dem af princip, 
men selvfølgelig opsøger jeg dem." [Interview F]

"Læringsmål er jo i sidste ende, hvad advokaten - altså censor - sidder og skal vurdere ud fra. Læringsmålene gør én mere tryg ved eksamen, fordi det bliver mere klart, hvad man bliver vurderet ud fra. Det er jo nemmere, end når man ikke ved det." [Interview A]

Men hensyn til de studerendes kollektive anvendelse af læringsmål synes der at være en tendens til, at kvalifikationsbeskrivelserne i højere grad kommer på banen de studerende imellem, når eksamen nærmer sig. Mens blot hver fjerde studerende (28 \%) angiver, at læringsmål enten i høj grad eller nogen grad bliver diskuteret med medstuderende som forberedelse til undervisningen, gælder det samme for 86 \% af respondenterne, når det gælder forberedelse af mundtlig eller skriftlig eksamen. De studerende, vi har interviewet, ligger alle på linje med disse svar. En studerende fortæller:

"Jeg opsøger dem [læringsmålene], når jeg påbegynder et modul som regel. For lige at orientere mig om, hvad handler det her modul om (...). Så opsøger jeg det første gang, vi taler om eksamen, som regel. Og så opsøger jeg det nok igen, når jeg sidder med min eksamen (...), [hvor] det kan være, vi lige skal tjekke, at vi er på rette vej." [Interview C]

På uddannelsesvidenskab er timenormerne til individuel vejledning blevet reduceret markant inden for de seneste to år og (delvis) erstattet af andre vejledningsformer som kollektiv vejledning og peer feedback. I den sammenhæng udtrykker en studerende, at hun ser en form for substitutionsforhold mellem vejledning og selvstudium af læringsmål:

"Jeg er blevet mere opmærksom på at bruge dem [læringsmålene]. Jeg har nok ikke været så orienteret mod dem - faktisk gennem hele bacheloren, men her på kandidaten er jeg nok. Fordi vi [grundet besparelser på uddannelsen] heller ikke har den her individuelle vejledning længere, så er jeg ligesom blevet nødt til at orientere mig mod at se: Hvad er det så, vi skal i opgaverne? Så det er blevet en nødvendighed at skulle prøve at forstå dem." [Interview B]

Sammenfattende for analysespor 2 kan man sige, at læringsmål hovedsageligt interesserer de studerende på to bestemte tidspunkter $i$ et undervisningsforl $\emptyset$ : indledende som et instrument til at skabe fagligt overblik og henimod slutningen af et semester som forberedelse til eksamen. Det er en nærliggende antagelse, at dette skal ses i sammenhæng med, hvornår underviserne tager læringsmål op i undervisningen. Som et løbende arbejdsredskab har læringsmålene hidtil været af mindre interesse. Når de anvendes, er det i overvejende grad individuelt frem for kollektivt. Vores interviewmateriale peger endvidere på, at en mere koncentreret brug af læringsmål blandt de studerende kan udgøre en delvis erstatning, fra de studerendes synsvinkel nok mest et surrogat, for nedgangen i timenormerne til individuel vejledning. Et gennemgående fokus på tærskelbegreber i undervisningen vil efter vores vurdering her kunne virke understøttende for de studerendes eget arbejde med læringsmålene ved at binde kernebegreberne op på nogle samlende begrebsstørrelser.

\section{Analysespor 3: De studerendes kritiske stillingtagen til læringsmål}

Som det tredje og sidste analysespor har vi unders $\varnothing$ gt de studerendes holdning til læringsmål. Vi interesserer os her for to forhold: Oplever de studerende, at læringsmål understøtter deres læring? Og finder de, at der er konsistens i, hvor meget og hvordan undervisere inddrager læringsmål i deres undervisning? 
Omkring $80 \%$ af de studerende i vores survey angiver, at deres undervisere enten i høj eller i nogen grad præsenterer og gennemgår modulets læringsmål i begyndelsen af et semesterforløb (figur 4).
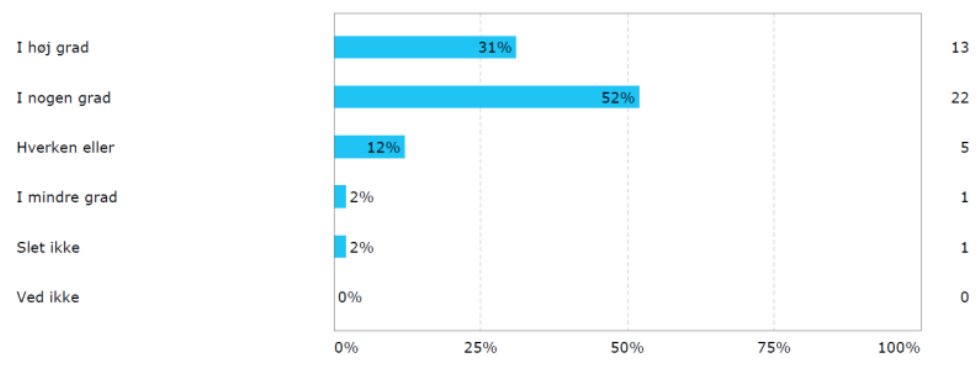

Figur 4: I hvor høj grad passer følgende udsagn på dig? - Mine underviser(e)/ vejleder(e) forklarer læringsmålene i begyndelsen af modulet/faget

Til gengæld tyder vores interviewmateriale på, at det er forskelligt, hvor dybt underviserne går ned i materien. Én studerende sætter disse ord på synspunktet, som også, i varierende form, gengives af de seks $\varnothing$ vrige interviewpersoner:

"Det synes jeg er meget forskelligt. Nogle er rigtig gode til at sige: Det hér er, hvad vi skal igennem, og hvad vi som udgangspunkt lægger op til, at I kan lære. Andre siger: I kan læse studieordningen. Jeg synes, at det er rigtig fedt, når læringsmålene bliver uddybet, fordi de tit er meget brede. Fedt, når man får sat nogle ord på." [Interview D]

Flere af de interviewede studerende giver udtryk for, at læringsmålene kræver mere indgående behandling i undervisningen og ikke blot bør fremstilles som bullets på et PowerPoints-slide den første og sidste undervisningsgang. Underviseren må med andre ord gerne udlægge læringsmålene og bruge tid på dem; ellers er der risiko for, at de forbliver mere eller mindre indholdsløse ord. To af de interviewede studerende siger om deres erfaringer fra tidligere undervisning:

"Jeg tror aldrig, at jeg har læst læringsmålene og tænkt: Det er bare knivskarpt, og nu er jeg bare helt med på, hvad jeg skal igennem, og hvad jeg bliver vurderet på. Det bliver jo ofte præsenteret med brede penselstrøg, så de også kan gradbøjes." [Interview A]

"Som sagt kan der godt være nogle, der bare klasker dem [læringsmålene] op og siger: Nu kan I se, at jeg har forholdt mig til, hvad det er, vi skal i dag. Men så bliver der ikke rigtig nogle yderligere refleksioner over, hvad det indeholder, eller fulgt op på det særligt tit. Der mangler en eller anden refleksion, vil jeg da generelt sige." [Interview E]

Dér hvor flere studerende udtrykker, at inddragelsen af læringsmål kan blive problematisk, er, når de kobles for entydigt til eksamen. Faren her er, at læringsmål hurtigt kan komme til at styre for meget, så det går ud over studieglæden og selve processen med at lære. En studerende udtrykker det på denne måde:

"Man skal jo heller ikke se det [læringsmålene] som et fængsel, som man skal sidde inden for, og så sigte efter den eksamen fra starten af, og det er det, som jeg tror, er svært som underviser at få os ud over: Jamen, vi skal jo tale om eksamen, fordi vi skal allerede begynde at tænke over det nu, og vi er lige startet jo, og det er et langt forløb. Men det er jo faktisk ikke meningen, at det skal sidde som sådan en ond ramme." [Interview C] 
Når det gælder sammenhængen mellem læringsmål og det, der foregår i undervisningen, mener hver fjerde ( $24 \%)$, at underviserne kun "i mindre grad" relaterer undervisningens indhold og aktiviteter til læringsmålene, mens yderligere $12 \%$ angiver "hverken/eller". Knap halvdelen (48 \%) svarer "i nogen grad" (figur 5).
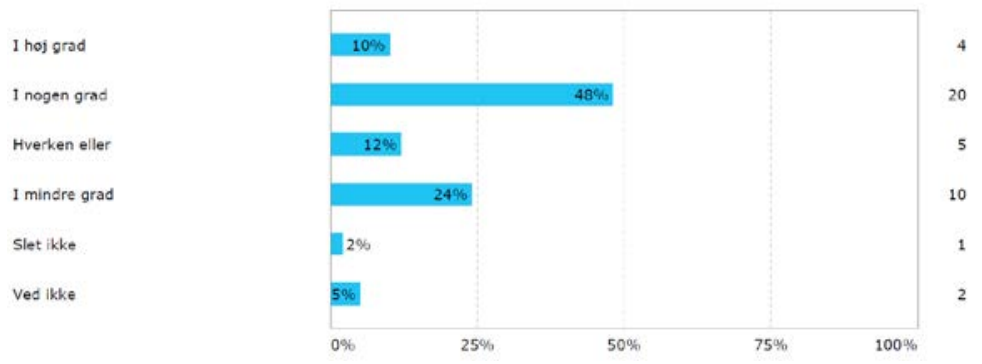

Figur 5: I hvor høj grad passer følgende udsagn på dig? - Mine underviser(e) /vejleder(e) relaterer undervisningens indhold og aktiviteter til læringsmålene

Det tyder altså på, at mange studerende har svært ved at se forbindelsen mellem læringsmålene og undervisningens indhold.

Opsamlende for analysespor 3 kan vi konkludere, at de studerende har et noget blandet forhold til de læringsmål, som omkranser og betinger deres uddannelse. Læringsmål kan potentielt virke underst $\varnothing t t e n d e$ for de studerendes læring, men det kræver, at underviseren inddrager dem reflekteret og gerne uden (alt for) stærk kobling til eksamen.

\section{Konklusion}

Vi valgte at operationalisere vores forskningsspørgsmål gennem tre analyseanalysespor: de studerendes forståelse af læringsmål, de studerendes brug af læringsmål og de studerendes holdning til læringsmål. Med hensyn til det første analysespor tyder resultaterne af de gennemførte interviews på, at viden om konteksten for selve institutionen læringsmål hos de studerende er spredt. Også hvad angår læringsmålenes tydelighed, hersker der forskellige anskuelser blandt de studerende.

Hvad angår det andet delspørgsmål om de studerendes brug af læringsmål, peger undersøgelsen på, at såvel undervisere som studerende hovedsagelig beskæftiger sig med læringsmålene for et modul ved semesterets begyndelse og op til eksamen, men ikke så meget derimellem. Desuden finder vi, at brugen af læringsmål er betydeligt mere individuelt end kollektivt baseret hos de studerende.

I vores tredje analysespor undersøgte vi de studerendes holdning til læringsmål. Her fandt vi, at nogle studerende synes at have et ambivalent forhold til læringsmål: På den ene side efterspørger de en nærmere sammenhæng mellem læringsmål og undervisningens indhold. På den anden side må underviseren ofte praktisere en fin balancegang, da de studerende heller ikke ønsker, at læringsmålene kommer til at dominere over indholdet og pege alt for tydeligt frem mod eksamen.

Samlet set peger undersøgelsen på, at man som underviser har en vigtig rolle med hensyn til at få de studerende til at forstå, bruge og forholde sig til læringsmålene for et modul. Hvis ikke læringsmålene inddrages i undervisningen, risikerer de i bedste fald kun at blive brugt til eksamen, hvor de studerende fortolker dem individuelt, og i værste fald overhovedet ikke at blive brugt. En 
øget bevidsthed om tærskelbegreber som den lim, der binder kvalifikationsbeskrivelsens kernebegreber sammen, kan være en vej til at sætte læringsmålene mere i centrum af undervisningen.

Thomas Clausen, adjunkt, ph.d. ved Danmarks Institut for Pædagogik og Uddannelse (DPU), Aarhus Universitet. Han underviser og forsker i offentlig forvaltning af uddannelse og uddannelsesinstitutioner samt i uddannelsesøkonomi. Han arbejder aktuelt bl.a. på et forskningsprojekt om uddannelsesstøttens historie i Danmark med særlig henblik på forvaltningen af Ungdommens uddannelsesfond i perioden 1952-1970.

Helle Hvass, konsulent ved Center for Undervisningsudvikling og Digitale Medier (CUDiM) - Team for Didaktisk udvikling, Emdrup. Helle Hvass er cand.mag. i retorik og fransk, forfatter til en række lærebøger om retorik og censor gennem 20 år på KU og AU. Hun arbejder med undervisningsudvikling og uddannelseskompetence, primært inden for områderne akademisk skrivning, akademisk læsning, mundtlig akademisk fremstilling og peer feedback. Hun deltager $i$ udviklingsprojekter, fx om kollektiv akademisk vejledning og revision af adjunktpædagogikum.

\section{Referencer}

Altbach, Philip G., Liz Reisberg og Laura E. Rumbley (2009): Trends in Global Higher Education: Tracking an Academic Revolution, UNESCO.

Andersen, Hanne Leth og Jens Christian Jacobsen (2012): "Centrale begreber i den internationale uddannelsesdiskurs: En politisk rammesætning", i Hanne Leth Andersen og Jens Christian Jacobsen (red.): Uddannelseskvalitet i en globaliseret verden. Samfundslitteratur, pp. 1730.

Biggs, John og Catherine Tang (2011): Teaching for Quality Learning at University. Open University Press.

Brøgger, Katja og Thomas Clausen (2017): "Uddannelsesstyring- og forvaltning", i Anders Kruse Ljungdalh, Jonas A. Lysgaard og Oliver Alexander Tafdrup (red.): Uddannelsesvidenskab. En kritisk introduktion. Samfundslitteratur, pp. 155-174.

Bundsgaard, Jeppe og Morten Rasmus Puck (2016): Nationale test: Danske lærere og skolelederes brug, holdninger og viden. DPU, Aarhus Universitet og Center for Anvendt Skoleforskning, University College Lillebælt.

Caspersen, Joakim, Jens-Christian Smeby og Per Olaf Aamodt (2017): “Measuring learning outcomes", European Journal of Education, Vol. 52, 1, pp. 20-30.

CEDEFOP (2009): The shift to learning outcomes. Policies and practices in Europe.

Christensen, Jørgen Grønnegård, Peter Munk Christiansen og Marius Ibsen (2017): Politik og forvaltning. Hans Reitzels Forlag.

Clement, Sanne Lund (2017): "I respondentens sted: Forståelse, viden og hukommelse", i Frederiksen, Morten, Peter Gundelach og Rikke Skovgaard Nielsen: Survey. Design, stikprøve, spørgeskema, analyse. Hans Reitzels Forlag, pp. 101-114.

Danmarks Akkrediteringsinstitution (2017): Akkrediteringsrapport. Aarhus Universitet. Institutionsakkreditering. 
Danmarks Evalueringsinstitut (2013): Evaluering af den danske kvalifikationsramme for livslang læring.

Davies, Peter og Jean Mangan (2007): "Treshold concepts and the integration of understanding in economics", Studies in Higher Education, Vol. 32, No. 6, pp. 711-726.

Dobbins, Kerry, Sara Brooks, Jon J.A. Scott, Mark Rawlinson og Robert I. Norman (2016): “Understanding and enacting learning outcomes: the academic's perspective", Studies in Higher Education, 41:7, pp. 1217-1235.

Hussey, Trevor og Patrick Smith (2003): "The Uses of Learning Outcomes", Teaching in Higher Education, 8:3, pp. 357-368.

Jensen, Mads Dagnis og Jon Kvist (2016): "Hvordan laver man en stærk analysestrategi", i Catharina Juul Kristensen og M. Azhar Hussain (red.): Metoder i Samfundsvidenskaberne. Samfundslitteratur, pp. 39-55.

Keiding, Tina Bering (2016): Didaktiske perspektiver på og vejledning til udarbejdelse/revision af studieordninger. Center for Undervisningsudvikling og Digitale Medier, Aarhus Universitet.

Keiding, Tina Bering og Ane Qvortrup (2015): "DUT som didaktisk felt - en empirisk analyse af didaktiske temaer i perioden 2006-2013", Dansk Universitetspædagogisk Tidsskrift, nr. 19, pp. 8-21.

Keiding, Tina Bering og Josefine Dalum Hansen (2012): "Undervisningens indhold - universitetsdidaktikkens stedbarn", Dansk Universitetspædagogisk Tidsskrift, nr. 13, pp. 106-119.

Kvale, Steiner og Svend Brinkmann (2015): Interview - det kvalitative forskningsinterview som håndværk, Hans Reitzels Forlag.

Land, R., G. Cousin, J. Meyer og P. Davies (2005): "Threshold concepts and troublesome knowledge: implications for course design and evaluation", i C. Rust et al: Improving student learning, diversity and inclusivity. Oxford Centre for Staff and Learning Development, pp. 53-64.

Meyer, Jan, og Ray Land (2003): Threshold Concepts and Troublesome Knowledge: Linkages to Ways of Thinking and Practising within the Disciplines, Occasional Report 4.

Olsen, Johan P. (1978): "Folkestyre, byråkrati og korporativisme - skisse av et organisasjonsteoretisk perspektiv", i Johan P. Olsen (red.): Politisk organisering, Universitetsforlaget, pp. 13114.

Rathlev, Jakob, Jonathan Hermansen og Hans Bay (2017): "Dataindsamling", i Frederiksen, Morten, Peter Gundelach og Rikke Skovgaard Nielsen: Survey. Design, stikprøve, spørgeskema, analyse. Hans Reitzels Forlag, pp. 55-87.

Referencegruppen om en ny dansk kvalifikationsramme for videregående uddannelser (2007): Ny dansk kvalifikationsramme for videregående uddannelser.

Reinecker, Lotte, Peter Stray Jørgensen, Jens Holin og Gitte Holten Ingerslev (2013): Universitetspædagogik. Samfundslitteratur.

Schmidt, Elsa (2006): "Bedømmelsens kompleksitet", Dansk Universitetspædagogisk Tidsskrift, nr. 1, pp. 6-12. 
Sin, Christina (2013): "Lost in translation: the meaning of learning outcomes across

national and institutional policy contexts", Studies in Higher Education, Vol. 39, No. 10, pp. 18231837.

Thingholm, Hanne Balsby et al. (2016): Navigating in Higher Education - NiHE. Et blik fra studerende og undervisere på faglige, sociale og personlige perspektiver på undervisningen. Aarhus Universitet.

Uddannelses- og Forskningsministeriet (2017): Uddannelses- og Forskningspolitisk Redegørelse.

Uddannelses- og Forskningsministeriet (2016a): Bekendtgørelse om bachelor- og kandidatuddannelser ved universiteterne (uddannelsesbekendtgørelsen).

Uddannelses- og Forskningsministeriet (2016b): Bekendtgørelse om eksamen og censur ved universitetsuddannelser (eksamensbekendtgørelsen).

Uddannelses- og Forskningsministeriet (2015): Bekendtgørelse af lov om universiteter (universitetsloven). 